\title{
How Public Transportation Use Social Media Platform during Covid-19: Study on Jakarta Public Transportations' Twitter Accounts?
}

\section{Eko Priyo Purnomo}

Department of Government Affairs and Administration, Jusuf Kalla School of Government, Universitas Muhammadiyah Yogyakarta, Indonesia. E-mail: eko@umy.ac.id

\section{Mohammad Jafar Loilatu*}

Department of Government Affairs and Administration, Jusuf Kalla School of Government, Universitas Muhammadiyah Yogyakarta, Indonesia. E-mail: jafar.loilatu@gmail.com

\section{Achmad Nurmandi}

Department of Government Affairs and Administration, Jusuf Kalla School of Government, Universitas Muhammadiyah Yogyakarta, Indonesia.E-mail: nurmandi_achmad@umy.ac.id

\section{Salahudin}

Department of Government Studies, Universitas Muhammadiyah Malang, Indonesia.

E-mail: salahudin@umm.ac.id

\section{Zuly Qodir}

Department of Government Affairs and Administration, Jusuf Kalla School of Government, Universitas Muhammadiyah Yogyakarta, Indonesia. E-mail: zuliqodir@umy.ac.id

\section{Iradhad Taqwa Sihidi}

Department of Government Studies, Universitas Muhammadiyah Malang, Indonesia.

E-mail: iradhad@umm.ac.id

\section{Muhammad Lutfi}

Department of Government Studies, Universitas Muhammadiyah Sinjai, Indonesia.

E-mail: lutfigov@gmail.com

Received November 06, 2020; Accepted December 12, 2020

ISSN : $1735-188 X$

DOI: $10.14704 / W E B / V 18 I 1 / W E B 18001$

\section{Abstract}

This study aims to analyze the social media functions of Jakarta public transportation during the COVID-19 pandemic. We analyze four twitter accounts of Jakarta public transportation consisting of LRT, MRT, BRT, and Commuter Line. The method in this study uses qualitative content analysis and Nvivo 12 Plus analysis tool. Based on the content analysis, the information that has given during the pandemic includes COVID-19, transportation 
information, risk information, and community information during the pandemic period. We have divided the function of twitter account into five categories: First, providing information related to some schedule changes, and functions before and during pandemic. Second, reporting situation, this category shall convey information on the condition of corridors, and terminals. Third, communication of risks, related to health and service standards during the COVID-19 pandemic, as a campaign for transport users in Jakarta to be aware of the surrounding conditions. Fourth, providing mental assistance, this function shall be in the form of COVID-19 prevention through the provision of disinfectant boxes, the use of hand sanitizers, and the provision of health counseling, and the fifth is service information.

\section{Keywords}

COVID-19, Transportation, Crisis, Communication, Social Media.

\section{Introduction}

An emergency situation occurs when disturbances to normal conditions appear. In this particular period, the community requires very complex information. (Martínez-Rojas, Pardo-Ferreira, \& Rubio-Romero, 2018) The main challenge in this condition is the management and sharing of appropriate information (Panagiotopoulos, Barnett, Bigdeli, $\&$ Sams, 2016). In emergencies or social media crises, it can be used to respond the situations by sharing information through public authorities, or the society (Anson, Watson, Wadhwa, \& Metz, 2017). Large cities use social media as the public communication with a good monitoring system (Costa et al., 2018), also monitoring information serves to determine the condition of the location or service during an emergency.

The use of social media information can be filtered with specific topics related to crisis conditions (Y. Wang, Wang, Ye, Zhu, \& Lee, 2016), this information is useful in the process of monitoring cities with high density (Pezanowski, MacEachren, Savelyev, \& Robinson, 2018). Besides, social media is an information tool where authorities can provide information by identifying the scene and transferring information in real-time (Bonsón, Perea, \& Bednárová, 2019). Large cities use social media as a communication tool, where information communication and technology (ICT) become an important part of managing the city (Bifulco, Tregua, Caterina, \& Anna, 2016). ICT is applied for service efficiency by providing real-time and correct information through social media. So, the public can see the physical aspects of the city, public facilities, and public services that has provided (Arribas-bel, Daniel; Kourtit, Karima; Nijkamp, Peter; Steenbruggen, 2019). 
On $3^{\text {rd }}$ March 2020, Indonesia has announced first case of COVID-19 in Jakarta. The number of cases continues to increase each day. The gradual spread of COVID-19 has mainly caused by community and public activities, despite the stipulation of social distancing policies and the elimination of activities that triggered the crowd. Further more on $31^{\text {st }}$ March, the total number of confirmed cases in Jakarta has reached up to 747 cases, with 48 negative cases, and total deaths were 83. While in April, the number of Jakarta cases has increased up to 4175 cases, with 486 negative cases, and reached 371 deaths (COVID-19.go.id). In March, the Government of Indonesia established a state of health emergency through Presidential Decree Number 11 the year of 2020, concerning the Establishment of a Corona Virus Disease Public Health Emergency, this policy shows that emergencies are needed throughout the Indonesian territory.

Jakarta has become a province with the highest confirmed cases in Indonesia. However, the transportation services were still running. After the establishment of a health emergency status, the Jakarta government imposed the Large-scale Social Restrictions (PSBB) as an option to replace lockdown or partial lockdown. This policy is expected to be effective for the transport services to adjust with the current situation. The PSBB policy in Jakarta only temporarily limits the service hours while observing the development of new cases. The government's policy to grant permission for Jakarta's public transportation to operate has the potential to cause the spread and infectious virus to increase, the high mobility of the community can transmit the virus for using public transportation.

In addition the United Nations has declared that COVID-19 is a global virus that attacks all countries and results in crisis (Atkinson, 2020), or global emergency (Nicola et al., 2020). Facing COVID-19, World Health Organization (WHO) has established a strategy to reduce transmission of the virus by risk communication (WHO, 2020c). WHO recommends the right action to provide proper information, information at the right time, and information to the right person. For the sake of those reasons, the awareness of all parties to comply health protocol is highly needed to avoid worsening condition.

Risk communication is an emergency function that serves to provide understanding to the public about the dangers of COVID-19. WHO has set communication standards in COVID-19 conditions to prevent misinformation, rumors, can detect events and respond to public complaints (UNDCO and WHO, 2020). In these conditions, social media is very beneficial, especially during crisis and health emergencies, people need information either the response of the community, government or organizations to crises and emergencies 
(Yoo, Rand, Eftekhar, \& Rabinovich, 2016), social media becomes a precise, fast, and real-time information platform.

In responding thus issues, the official of Jakarta public transportation uses the twitter platform as a communication tool. Twitter is a social media that is highly used by individuals, organizations, and governments. Twitter has become a campaign platform for something that is considered important. Ngamassi, Ramakrishnan, \& Rahman, (2016) see the steps that can be taken in a crisis situation are preparation, mitigation, respond, and recover. Those actions must be suitable with WHO (WHO, 2019) public service and risk communication protocols. Twitter as a communication and campaign tool against COVID-19 prevention can also be referred to the risk communication (WHO, 2020a). The term of risk communication and community engagement mean that the accuracy of information needs to be delivered through official media. The massive data could possibly cause false perception and creates fear among society. So, the information needs to be filtered and clearly conveyed through official institutional platforms (Cinelli et al., 2020).

Therefore, this study looks at the risk communication model in the health emergencies conducted by Jakarta transportation in providing services through Twitter. Jakarta as the province with the highest number of cases but the government does not impose a total lockdown and ultimately had an effect on the high mobility of the people. We tend to see how to model the right action of the Jakarta transportation through social media platform. Also, this paper discusses about several twitter accounts of Jakarta Transportation. Those are Bus Rapid Transit (BRT), Mass Rapid Transit (MRT), Light Rapid Transit (LRT), and Commuter Line accounts. The study answers the risk communication model of Jakarta public transportation service providers.

\section{Literature Review}

\section{Risk Communication on Social Media}

A big challenge in emergencies is the proper management and sharing of information (Panagiotopoulos et al., 2016), social media can be used in responding to emergencies by sharing information (Anson et al., 2017). Social media as a public communication tool with a good monitoring system (Costa et al., 2018). Monitoring information serves to determine the condition of the location or service, social media makes information can be filtered with specific topics related to crisis conditions, the information is useful for the supervision of services (Pezanowski et al., 2018). In addition, social media as an information tool where everyone can contribute to provide information by identifying the scene and transferring in real-time (Bonsón et al., 2019). 
The COVID-19 is a virus that spreads throughout the world. In these conditions, countries need precise information in order to prevent the symptoms and diseases. In this context, social media can be used during crisis or post-crisis conditions, so every information that has been delivered properly will be responded appropriately as well. Aside from being a communication tool, it also has the function as a risk management (Panagiotopoulos et al., 2016). Twitter can be a national and global health detection tool by providing correct information through society or individuals (Abd-Alrazaq, Alhuwail, Househ, Hamdi, \& Shah, 2020). Twitter can accumulate data and provide an evaluation of the service activities. (Martín, Julián, \& Cos-Gayón, 2019). In this situation, twitter can be used during an emergency with COVID-19 procedures, because risk communication can work properly with the shared information. According to Son, Lee, Jin, \& Lee, (2019) risk communication aims to provide understanding to the community, and provide exact and recovery when facing an emergency.

\section{Public Health Communication Using Social Media}

Social media is considered to be the right place to find and provide health information (Park, Reber, \& Chon, 2016). Health information usually delivered by public organizations, health organizations, service organizations, and others. The news gives an influence for the community to take preventive actions (Lachlan, Spence, Lin, Najarian, \& Del Greco, 2016). Thus, we need to understand that every organizations, and service providers, or even individuals could deliver and receive proper information (Park et al., 2016). It is unfortunate that there are some sentiments in health information which results in misinterpretation towards the news in the society. (Roberts, Seymour, Fish, Robinson, \& Zuckerman, 2017). Hence, information clustering models can be used to filter every information. Interestingly, twitter can also be used as a policy-making tool, this is because Twitter is considered as an elite media in a crisis or emergency. As an elite media, Twitter combines interactive communication with other users, so information can be obtained from various sources (C. B. Zhang \& Lin, 2015).

\section{Social Media and Public Transportation}

Information on modern cities is conveyed through several applications connected with intelligent transport systems (ITS). The ITS system has the functions to translate data and deliver data to users. ITS is used to provide good transportation services, as a solution to the conditions of density, traffic jams, and delays (T. Wang, Hussain, Bhutta, \& Cao, 2019), so the function of social media to manage the information could be delivered quickly and cost-effectively (Cottrill et al., 2017) and integrated into public facilities 
(Kousiouris et al., 2018). Thus, managing the information is considered crucial as a basic strategy in fast and modern public services (Ebrahim \& Irani, 2005).

Sabani, Deng, \& Thai, (2019) explained that public transportation's social media supports the quality of services such as security information, quality information, functionality services, and transparency. In an emergency situation, information is needed especially related to health protocols and public transportation services. The World Health Organization has established a communication protocol in crisis conditions (WHO, 2019, 2020c), service protocol in public facilities (WHO, 2020b) so that people can avoid transmission of COVID-19. Xiao \& Torok, (2020) assessed that the most important thing in handling COVID-19 is to clearly communicate COVID-19 to service officers and the public in order to implement infection prevention and control measures, these steps can be determined through a policy strategy and management to avoid transmission of COVID19 (Henry, 2020).

Specifically, social media platform can also be useful as a traffic management, to inform schedule changes, departure, and termination of operations (Agency, 2010), so there is a need for media or public facilities that support those services (Grosvenor, 2016). By the using of twitter, public transport providers can identify a crowd that has the potential to transmit COVID-19 (Kwon, Grady, Feliciano, \& Fodeh, 2020). In order to understand that most countries affected by COVID-19 has limited mass activities, social distancing is the main approach to avoid increasing exponential cases (Feng, Damon-Feng, \& Zhao, 2020). Social distancing is intended to reduce the rate of transmission of new viruses because the community has reduced outdoor activities, and using public facilities (Hussain, 2020).

\section{Research Method}

\section{Data Collecting and Data Processing}

This research uses Qualitative Data Analysis (QDA) with computer programming assistant Nvivo 12 Plus (Brandão, 2015). Data translation in this study uses Nvivo 12 Plus, Nvivo 12 Plus Nvivo as tools of qualitative data analysis which translates data through several stages, (1) making new projects, (2) preparing documents, (3) coding data. (4) analysis (AlYahmady \& Al Abri, 2013), and (5) comparing (Woolf \& Silver, 2018). This study answers three problem formulations relating to risk communication of public transportation during COVDI-19. This research collects twit account using capturing (N-capture google), the data is related to COVID-19 information, data collection starts from April 10-May 31, 2020. This study chooses official twitter accounts 
of public transport that routinely provides information, we chose Jakarta transportation because it's connected to several cities such as Tangerang (Banten Province) and Bogor (West Java Province). Sources of data obtained through twitter accounts and official websites consisting of Light Rapid Transit account @1rtjkt and lrtjakarta.co.id, Mass Rapid Transit@mrtjakarta and jakartamrt.co.id, Bus Rapid Transit@@PT_Transjakarta and transjakarta.co.id, Commuter @CommuertIndonesia krl.co.id, this study selects an official account as a valid source of information on Jakarta transportation

RQ1: What is the risk communication model that has carried out by Jakarta transportation?

RQ2: What is the difference between the information conveyed by one transportation account and another?

RQ3: Does Jakarta's transportation implement health protocols based on the information provided?

\section{Qualitative Content Analysis}

This study uses qualitative content analysis (QCA), QCA as a systematic and flexible method for translating unstructured data (Kaefer, Roper, \& Sinha, 2015). Content analysis has been adapted to the term of Information Communication Technology ICT) by filtering or counting existing images and text (Neuendorf, 2017), content analysis of this study looks at the communication model by Jakarta transportation, online content or information that can be widely captured through (Google N-capture) and translated using Nvivo 12 Plus.

\section{Finding and Disscusion}

In the period of the COVID-19, the Government of Indonesia adopted several policies in dealing with this contagious outbreak. Some of the policies referred to include the determination of emergencies, large-scale social restrictions (PSBB), diversion of the budget, and permission for public transportation services. The government did not stop the operation of public transportation in Jakarta until the announcement of the surge increase of death cases that has reached more than 1000 on $12^{\text {th }}$ May. At the same time, the number of positive cases have always increased per day, also in Banten and West Java. As a preventive measure, the DKI Jakarta government enforces health protocols in the transportation service during emergency situation in order to reduce transmission of COVID-19. 
Public health response for COVID-19 contains some information for the traveler (Jernigan, 2020) including the update of the current condition of COVID-19. The government is taking steps to implement health protocols in accordance with WHO recommendations by disseminating information though channels and media so that it reaches the public. Jakarta Transportation uses two-way public information channels, this communication model gets various feedback from Twitter users to achieve dynamic and open communication. Jakarta Transportation is an integrated mass transportation system with high mobility and useful for the community to work. During this period of pandemic, WHO has provided some guidelines for the provision of public services in order to prevent COVID-19 transmission (WHO, 2019, 2020b), this step is a simple action that can be done. Risk education serves to enhance cooperation to overcome some problems. Risk communication has an important role especially in emergency situations (Qiu, Rutherford, Chu, Mao, \& Hou, 2011).

\section{Communication Model on Jakarta Transportation}

RQ1 in this study looked at the communication model that has carried out by Jakarta transportation. Updated service information helps Jakarta transportation users to find out the latest conditions and situations such as crowds, queues, and traffic jams. This information helps people to avoid crowded locations that have the potential to transmit the virus to other users. WHO has provided guidance for countries with COVID-19 to prevent the infection. Until today, COVID-19 has not been able to be be cured yet. In order to prevent the widespread of COVID-19, it is necessary to apply a health protocol and provide a guarantee for all the transportation users. First, we looked at the frequency of information by Jakarta transportation twitter accounts including @1rtjkt, @mrtjakarta, $@$ @T_Transjakarta, and @commuterline. The intensity of the information announced variously. Those accounts are actively providing information regarding activities during the COVID-19 period, see figure (1).

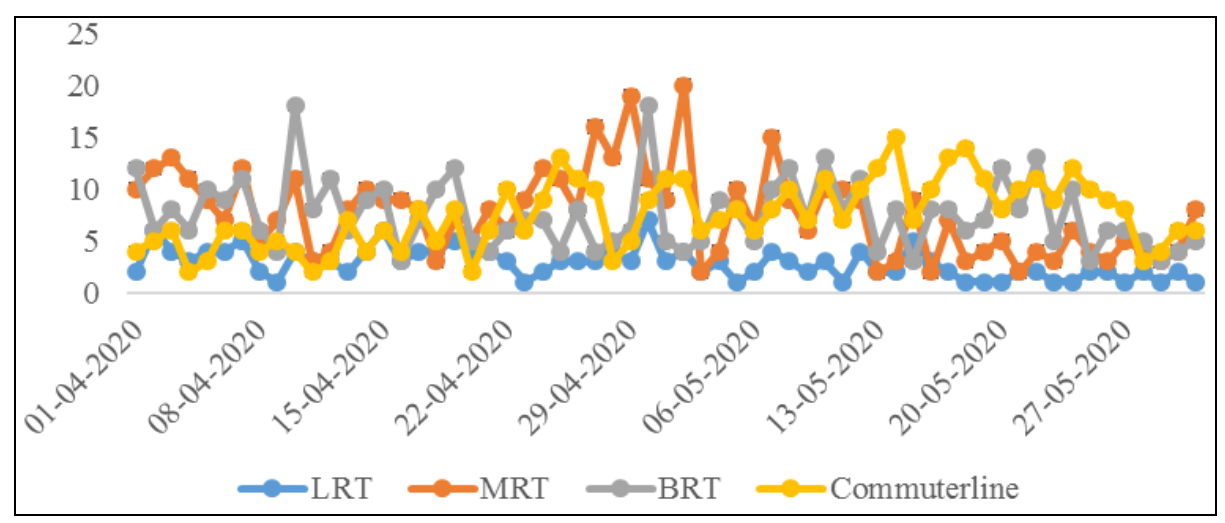

Figure 1 Tweet per Day 
Based on the figure (1), the Twitter account with the highest number of tweets is the Commuter Line @commuterline account with 490 total tweets, BRT @PT_Transjakarta with 455 tweets, MRT @mrtjakarta 423 tweets and the lowest in the @1rtjakarta account with only 172 tweets. The frequency of tweets in figure (1) looks quite volatile, except for the LRT account where the intensity of the information did not experience a significant increase.

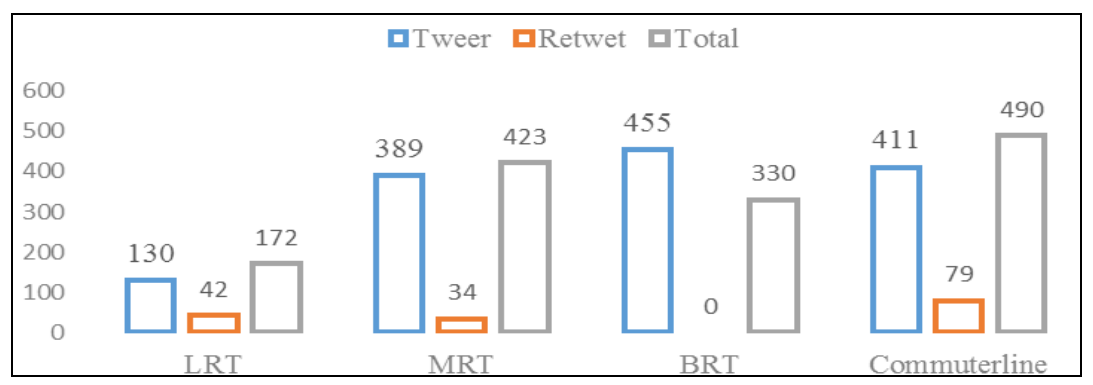

Figure 2 Total Tweet

Information during the COVID-19 pandemic has physical characteristics that can be identified with a hashtag that is often used by Jakarta transportation accounts. Figure (3) below shows the hashtag that has been used, such as; stay at home, fight Covid-19, tije respond corona, let's wear a mask, physical distancing, Jakarta respond Covid-19. The information presented by these accounts related to the application of risk communication and health protocols in Jakarta transportation services. Stay at home has the highest hashtag with 295 hashtags and it is related to the government's call for the community to be active and productive at home during the pandemic. The hashtag let's wear masks is related to the government policies that require the use of masks in public areas. Other hashtags such as Jakarta respond COVID-19, tije respond COVID-19, lrt jaki, are hashtags that are used as Jakarta's identity and Jakarta's public transportation.

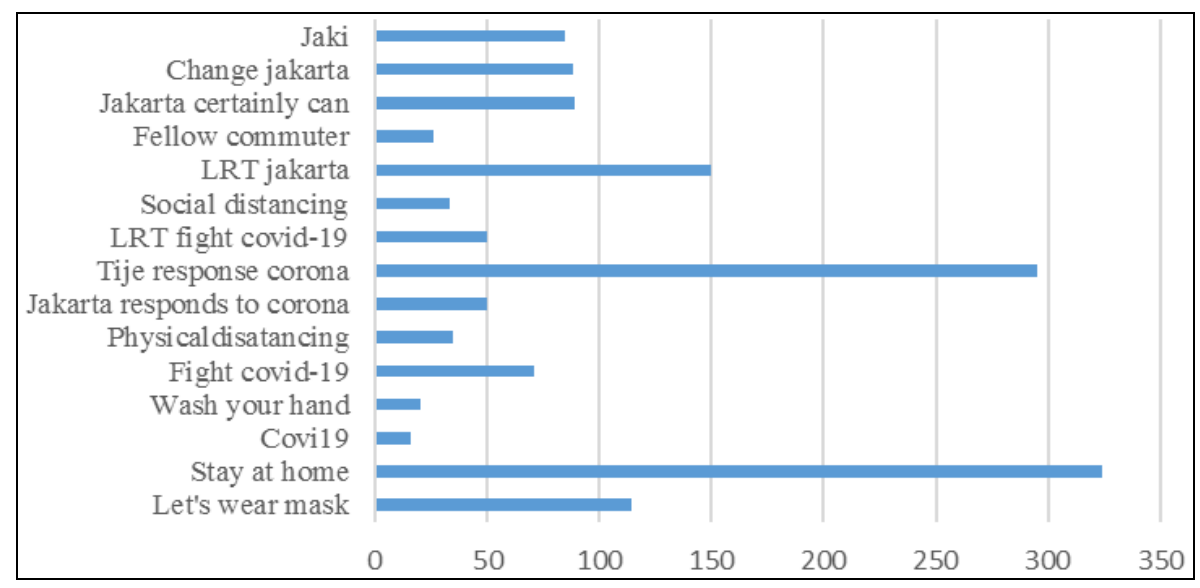

Figure 3 Sample Hashtag of Jakarta Transportation 
The hashtag became a campaign for the public to help everyone easier to find out the latest information about health services and protocols provided by Jakarta transportation. Central of Research and Control and Prevention (CDC), the World Health Organization (WHO) has used social media in crisis conditions. The public gives various responses to the social media information with the principle of risk communication by combining image and audio visualization (Guidry, Jin, Orr, Messner, \& Meganck, 2017). All the submitted information, and the updated news that has been clustered from April 10 to May 31 are related to the development of COVID-19, and related to public health (Roberts et al., 2017).

\section{What is the Difference between the Information in each Transport Accounts?}

RQ 2 in this study answers the differences between the information conveyed by each Jakarta public transport account. By using QCA, we analyze the word frequency of information by the Jakarta transportation twitter account. QCA filters the highest number of words and has links to the researched topic. Figure (4) below is the LRT account word frequency and figure (5) MRT, both have the same information characteristic with a different number of words. The LRT contains information about the LRT's response to COVID-19 by conducting a mask use campaign, implementing a PSBB policy by limiting service hours. The word frequency contains information such as viruses, pandemics, and responsive. However, the intensity of information is low, see figure (1) number of tweets per day. Next, MRT has the word frequency such as home, PSBB, mask, pandemic, public, and wearing related to COVID-19. The information intensity of the MRT account is stable.

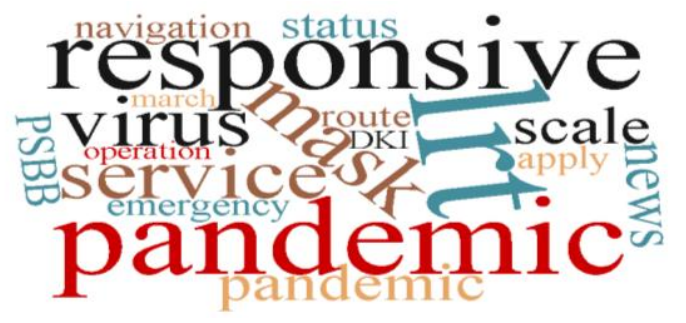

Figure 4 Word Cloud Official Account LRT

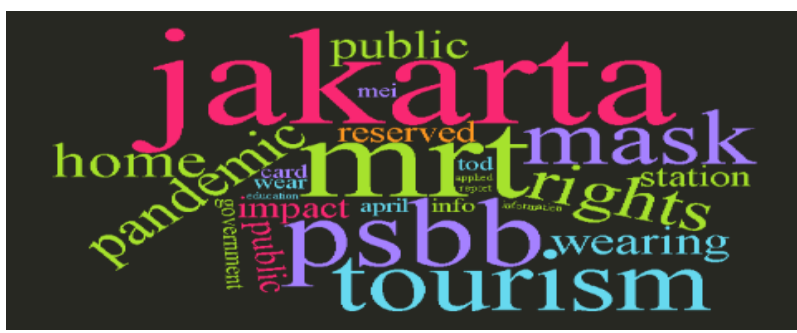

Figure 5 Word Cloud Offical Account MRT 
Social media users have characteristics that can be influenced by the presented information (Qiu et al., 2011), so those events can be identified by social media users (Kousiouris et al., 2018). We consider that the Jakarta Twitter account is a media that identifies information through other users who provide the same news. The forms of identification during the COVID-19 period is to impose social distancing for Jakarta transportation users.

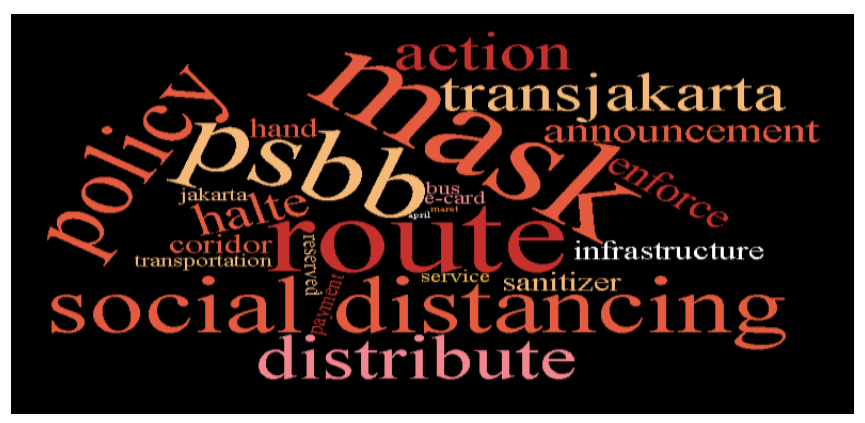

Figure 6 Word Cloud Offical Account BRT

Information about COVID-19 through the BRT Twitter account and the Jakarta Commuter Line delivered information about the application of the PSBB policy which also applies to the Jakarta BRT. The impact of the PSBB limits the hours of service of the Jakarta BRT so that information needs to be shared in detail about the service time and duration of services provided by the Jakarta BRT. In addition to that the BRT Jakarta also describes the procedure of using masks and hand sanitizers. Words like; trans Jakarta, PSBB, bus stops, routes, social distancing, infrastructure, corridor, are often used by BRT in providing information, see figure (6)

Commuter Line, during the PSBB policy has imposed in three provinces, including Jakarta, Banten and West Java, still operating normally. Commuter Line communicates service protocols to the public about the dangers and impacts of COVID-19 and the use of masks for Commuter Line passengers. Figure (7) is the word frequency of the Commuter Line twitter account, this account provides information about the socialization of the impact of COVID-19. Word frequency like case explains the positive case of COVID-19 to commuter line passengers. Other words such as; disability, safety mobility, transportation, schedule related to normal service with the aim of maintaining the safety of commuter line users. Referring to the view of Panagiotopoulos et al., (2016) about the function of social media Twitter as a crisis management tool, and also useful as a of mass mobilization tool. The form of mass mobilization under conditions of emergency is a form of public awareness in complying with the service protocol provided by Jakarta transportation. 


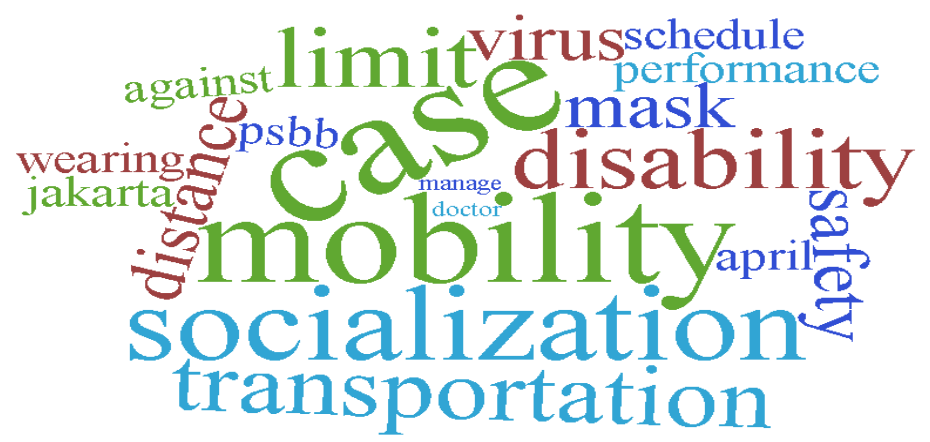

Figure 7 Word Cloud Offical Account Commuter Line

Show figure (8), the images contain the information submitted by the Jakarta LRT and MRT accounts about the health protocol provided by the LRT and MRT. The protocol is delivered by both accounts so users understand the health regulations and standards. Figure (8) shows similarity to Figure (4) and (5), that information about COVID-19 is delivered properly by the two accounts LRT and MRT.

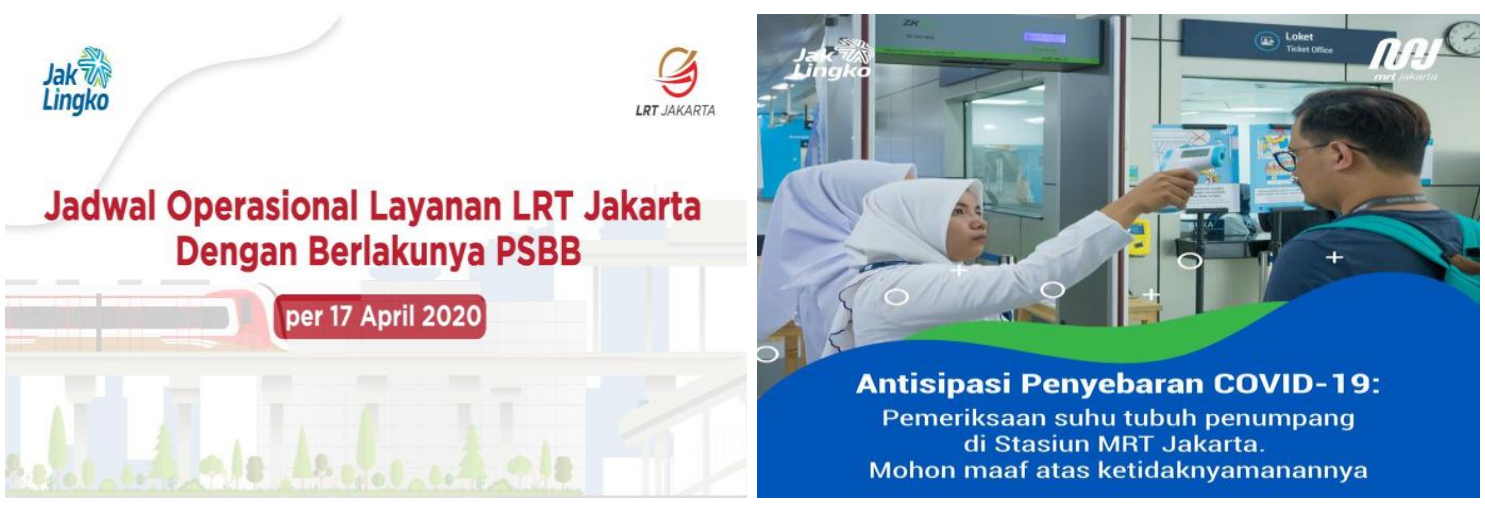

Figure 8 Protocol of Public Transportation Services LRT and MRT

White explain that LRT services are changed cause PSBB. Blue shows COVID-19 anticipation by MRT

Figure (9) below contains information from the Jakarta Commuter Line and BRT accounts. Both accounts provided information related to the service protocols during the COVID-19 pandemic. Information includes the form of service changes and adjustments to central and regional government policies regarding the determination of the emergency period, the determination of the PSBB policy, and an evaluation of the PSBB policy. Figure (9) shows that there is a similarity with figure (6) and (7) above, Figure (6) and (7) shows the information shared by both accounts, while figure (6) and (7) is direct information by Commuter Line twitter account and BRT account in the shape of the image, so the two images ( 8 and 9) have similarities in the form of information and are related to the handling of COVID-19. 

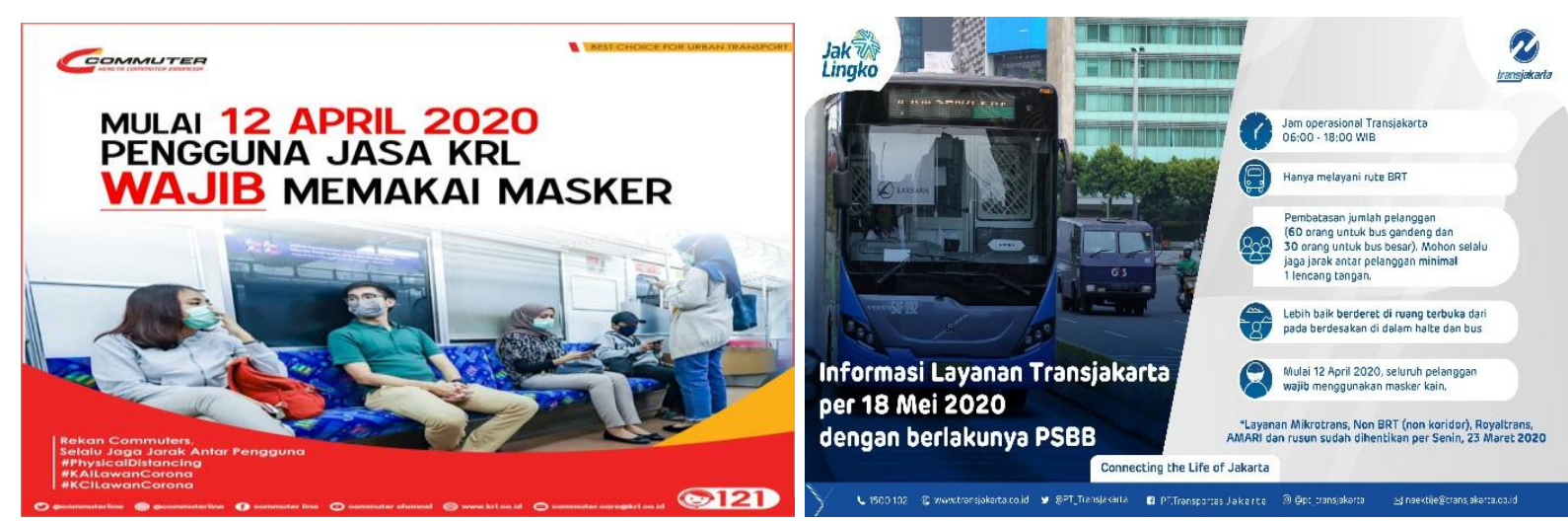

Figure 9 Protocol of Public Transportation Services Commuter Line and BRT

White explain the passenger must use a mask. Blue explaining the change in route due to the PSBB policy.

In the table (1) is a form of response to the Jakarta transportation twitter account during the COVID-19 pandemic period, the four accounts have the same answer. The form of the response is due to the policy and service protocol, we use (Ncapture) to take the list of questions assigned to the Jakarta transportation account, so the answers appear the table (1) below. The tweet category below is the form of questions given by Jakarta transportation users in searching for information (Bosley et al., 2013). As a city with a high population, twitter becomes a communication tool by providing community involvement in supporting information. (Molinillo, Anaya-Sánchez, \& LiébanaCabanillas, 2019; Molinillo, Anaya-Sánchez, Morrison, \& Coca-Stefaniak, 2019).

Table 1 Example and Category of Covid-19 Tweets

\begin{tabular}{|c|c|}
\hline Int & Answers Account \\
\hline LRT & $\begin{array}{l}\text { "@(user) LRT implement changes to service hours","@(user) limits the service hours from } \\
\text { 06:00 to 20:00", "@(user) let's keep our distance","@ (user) LRT applying standards of } \\
\text { cleanliness", "@(user) currently LRT serves the Pengangsang Dua route, Kelapa Gading } \\
\text { and Velodrome". }\end{array}$ \\
\hline MRT & $\begin{array}{l}\text { "@ (user) Bandung hilir MRT is not in operation", "@ (user) has no additional train during } \\
\text { COVID-19", "@ (user) MRT applies PSBB policy", closure of several stations related to } \\
\text { the PSBB "," @ (user) stay tune on our social media for the latest information","thank you } \\
\text { for the advice"," @(user) MRT operates from 6:00 to 18:00" }\end{array}$ \\
\hline BRT & $\begin{array}{l}\text { "@(user) We apologize for no sevice at this time"," @(user) The route is not in } \\
\text { operation"," @(user) All reports will be an evaluation"," @ (user) policies are applied to } \\
\text { reduce the distribution chain of COVID-19"," @(user) regular services are still operating } \\
\text { every day", }\end{array}$ \\
\hline $\begin{array}{l}\text { Commuter } \\
\text { Line }\end{array}$ & $\begin{array}{l}\text { "@(user) please contact us for more information ", "@(user) Sudirman-Bogor last } \\
\text { schedule at } 18.33 \text { "," @ (user) Bekasi-Jakarta at } 14.38 \text { WIB "," @ (user) we hope that our } \\
\text { commuter line users could pay attention to physical distancing ", "@ (user) This is an } \\
\text { effort to prevent the spread of COVID-19". }\end{array}$ \\
\hline
\end{tabular}




\section{Risk Communication on Jakarta Transportation}

RQ 3 uses the content analysis which means we search and select words that have content related to the topic. The use of word frequency in Nvivo 12 plus helps in searching for the word with the highest number so that it appears in table (1) below. Based on the word with the highest frequency, Covid-19 becomes the topic with the highest number of words with > 1000 and reached 1021. Previously, this study divided four topic categories; (1) Covid-19 topics, (2) information, (3) risk, and (4) community.

COVID-19 topic appears with words such as mask, health, social distancing, condition, stay at home, hand, washing, and others. The percentage of this topic is high at $12.27 \%$. Topics with the second-highest number of tweets is community, a number of tweets $>100$ $=(1036)$ with the percentage of $10.22 \%$. This topic illustrates the involvement of other groups who contributed in providing information about Covid-19. Information topic $<1000=(858)$, the topic is related to Jakarta's route information and transportation services such as corridor, card, health, train, business, and station. The topic of risk with a number of tweets (570) and a percentage of $6.60 \%$ are topics related to home, together, keeping, mask, hand, COVID-19, social distancing, and PSBB.

Table 2 Wordlist of Content Analysis

\begin{tabular}{|l|l|l|l|}
\hline Topic & Selected Words & $\begin{array}{l}\text { Number } \\
\text { of Tweets }\end{array}$ & $\begin{array}{l}\text { Tweets } \\
\text { Percentage }\end{array}$ \\
\hline Covid-19 & $\begin{array}{l}\text { Mask, health, social distancing, wearing, covid-19, } \\
\text { condition, stay at home, spearing, hand, washing, } \\
\text { together, April, stay safe, tije respond corona, psbb. }\end{array}$ & 1021 & 12.27 \\
\hline Information & $\begin{array}{l}\text { Route, operated, services, health, corridor, card, } \\
\text { train, buss, station }\end{array}$ & 858 & 9.30 \\
\hline Risk & $\begin{array}{l}\text { Home, together, keeping, wearing mask, hand, } \\
\text { covid-19, social distancing }\end{array}$ & 570 & 5.60 \\
\hline Community & $\begin{array}{l}\text { Friends, costumer, Indonesia, together, we, brother, } \\
\text { friends, Jakarta }\end{array}$ & 1036 & 10.22 \\
\hline
\end{tabular}

Social media works in all aspects; service, emergency, communication, or participation. Then, to answer on how is the function of Twitter in an emergency with the communication protocol and health standards by WHO. So, this study answers several communication models conducted by the Jakarta transportation twitter account. In general, the function of social media is to provide information, because it is a part of ICT development to meet the information needs of the community. Data analysis techniques on social media can be done by selecting information from many sources, so that they can 
read information quickly, provide support, and perform emergency management (C. Zhang, Fan, Yao, Hu, \& Mostafavi, 2019).

Table 3 Public Transportation Using Social Media During Covid-19

\begin{tabular}{|l|l|}
\hline Category & Description \\
\hline Giving information & $\begin{array}{l}\text { Provides information on the schedule for the clearance and schedule } \\
\text { changes due to COVID-19 }\end{array}$ \\
\hline Reporting situation & $\begin{array}{l}\text { Reporting the condition of the station, corridor, with high or low } \\
\text { queues. }\end{array}$ \\
\hline $\begin{array}{l}\text { Providing mental } \\
\text { support }\end{array}$ & $\begin{array}{l}\text { Delivering protocols for the use of public facilities by providing hand } \\
\text { sanitizers, disinfectant boxes, mask. }\end{array}$ \\
\hline Service Information & $\begin{array}{l}\text { Update information on route changes, departures, accidents, conducting } \\
\text { transportation }\end{array}$ \\
\hline
\end{tabular}

We divide the function of Twitter in the pandemic era into several categories, see table (3) above. (1) Giving information, including the operation changes from normal to pandemic situations, this category relates to bus or train departure schedules. (2) Reporting situation, this category presented information about the condition in the corridors, terminals, and bus stops caused by layoffs, queues of transportation users. (3) Risk communication, related to health and service standards during the COVID-19 pandemic, this serves as a campaign for all Jakarta transportation users to be aware of the surrounding conditions by conducting social distancing, wearing masks and reporting conditions if crowds occur at bus stops, corridors, or on buses and trains. (4) Providing mental support, this function is in the form of COVID-19 prevention by providing disinfectant boxes, using hand sanitizers, and health counseling provided by transportation service providers. (5) Service information, this category shared the information about route changes, departures, accidents, and conducting campaigns. Martin, Rice, \& Arthur,(2019) divided social media functions as predictive, experimental, and organizational functions. This this uses QSR Nvivo 11, while in this study we use QSR Nvivo 12 Plus. So, we divide social media in conditions of COVID-19 into five categories, see table (3).

\section{Conclusion}

The conclusion of this research that Jakarta transportation's risk communication during the COVID-19 pandemic has provided information and service protocols, although the intensity of information has delivered variously. The most active account in providing information are MRT and BRT. Both of these accounts have intensively conveyed information for Jakarta transportation users during the COVID-19 period. The 
information conveyed revolves around pandemic information, with the aim that transportation users could obey the guidelines such as wearing masks, keeping a distance, and avoiding crowds in transportation. This study also concludes that the function of Jakarta transportation's twitter account had mapped the type of information and carried out the risk communication function in accordance with WHO recommendation. The limitation of this research is the determination of the time used in retrieving data so the next researchers could explore further on the Jakarta transportation's social media function by looking at the development of COVID-19.

\section{Acknowledgment}

We would like to thank Jusuf Kalla School of Government for supporting and funding this research to completion for the COVID-19 project.

\section{References}

Abd-Alrazaq, A., Alhuwail, D., Househ, M., Hamdi, M., \& Shah, Z. (2020). Top concerns of tweeters during the COVID-19 pandemic: infoveillance study. Journal of medical Internet research, 22(4), e19016. https://doi.org/10.2196/19016

Agency, F.T. (2010). Road Traffic Management Strategy. Finnish Transport Agency.

AlYahmady, H.H., \& Al Abri, S.S. (2013). Using Nvivo for Data Analysis in Qualitative Research. International Interdisciplinary Journal of Education, 2(2), 181-186. https://doi.org/10.12816/0002914

Anson, S., Watson, H., Wadhwa, K., \& Metz, K. (2017). Analysing social media data for disaster preparedness: Understanding the opportunities and barriers faced by humanitarian actors. International Journal of Disaster Risk Reduction, 21, 131-139. https://doi.org/10.1016/j.ijdrr.2016.11.014

Arribas-bel, D., Kourtit, K., Nijkamp, P., \& Steenbruggen, J. (2019). A Poliot Study how Social Media can help teh Understanding of Cities. Universiy of Bormingham, 1-20. https://doi.org/10.1007/s12061-015-9154-2

Atkinson, C. (2020). G20 leaders must answer to COVID-19. Science, 368(6487), 111. https://doi.org/10.1126/science.abc1025

Bifulco, F., Tregua, M., Caterina, C., \& Anna, A. (2016). ICT adn Sustainability in Smart Cities Management. International Journal of Public Sector Management, 29(2), 132-147.

Bonsón, E., Perea, D., \& Bednárová, M. (2019). Twitter as a tool for citizen engagement: An empirical study of the Andalusian municipalities. Government Information Quarterly, 36(3), 480-489. https://doi.org/10.1016/j.giq.2019.03.001

Cinelli, M., Quattrociocchi, W., Galeazzi, A., Valensise, C.M., Brugnoli, E., Schmidt, A.L., Scala, A. (2020). The COVID-19 Social Media Infodemic. 1-18. http://arxiv.org/abs/2003.05004

Costa, D. G., Duran-faundez, C., Andrade, D.C., Rocha-junior, J.B., Paulo, J., \& Peixoto, J. (2018). TwitterSensing: An Event-Based Approach for Wireless Sensor Networks Optimization Exploiting Social Media in Smart City Applications. Sensors MDPI, 18(1080), 1-30. https://doi.org/10.3390/s18041080 
Cottrill, C., Gault, P., Yeboah, G., Nelson, J.D., Anable, J., \& Budd, T. (2017). Tweeting Transit: An examination of social media strategies for transport information management during a large event. Transportation Research Part C: Emerging Technologies, 77, 421-432. https://doi.org/10.1016/j.trc.2017.02.008

Ebrahim, Z., \& Irani, Z. (2005). E-government adoption: Architecture and barriers. Business Process Management Journal, 11(5), 589-611. https://doi.org/10.1108/14637150510619902

Feng, Z., Damon-Feng, H., \& Zhao, H. (2020). Sustaining Social Distancing Policies to Prevent a Dangerous Second Peak of COVID-19 Outbreak. MedRxiv, 2020.04.17.20069351. https://doi.org/10.1101/2020.04.17.20069351

Grosvenor, T. (2016). Qualitative Research in the Transport Sector.

Guidry, J.P.D., Jin, Y., Orr, C.A., Messner, M., \& Meganck, S. (2017). Ebola on Instagram and Twitter: How health organizations address the health crisis in their social media engagement. Public Relations Review, 43(3), 477-486. https://doi.org/10.1016/j.pubrev.2017.04.009

Henry, B.F. (2020). Social Distancing and Incarceration: Policy and Management Strategies to Reduce COVID-19 Transmission and Promote Health Equity through Decarceration. Health Education \& Behavior: The Official Publication of the Society for Public Health Education, 47(4), 536-539. https://doi.org/10.1177/1090198120927318

Hussain, A.H.M.B. (2020). Do Governments' Decisions on Social Distancing Flatten out People's Mobility during COVID-19 Pandemic? SSRN Electronic Journal. https://doi.org/10.2139/ssrn.3574979

Jernigan, D.B. (2020). Update: Public health response to the coronavirus disease 2019 outbreak - United States, 2020. Morbidity and Mortality Weekly Report, 69(8), 216-219. https://doi.org/10.15585/MMWR.MM6908E1

Kaefer, F., Roper, J., \& Sinha, P. (2015). A software-assisted qualitative content analysis of news articles: Example and reflections. Forum Qualitative Sozialforschung, 16(2). https://doi.org/10.17169/fqs-16.2.2123

Kousiouris, G., Akbar, A., Sancho, J., Ta-shma, P., Psychas, A., Kyriazis, D., \& Varvarigou, T. (2018). An integrated information lifecycle management framework for exploiting social network data to identify dynamic large crowd concentration events in smart cities applications. Future Generation Computer Systems, 78, 516-530. https://doi.org/10.1016/j.future.2017.07.026

Kwon, J., Grady, C., Feliciano, J.T., \& Fodeh, S.J. (2020). Defining Facets of Social Distancing during the COVID-19 Pandemic: Twitter Analysis. MedRxiv.

Lachlan, K.A., Spence, P.R., Lin, X., Najarian, K., \& Del Greco, M. (2016). Social media and crisis management: CERC, search strategies, and Twitter content. Computers in Human Behavior, 54, 647-652. https://doi.org/10.1016/j.chb.2015.05.027

Martín, A., Julián, A.B.A., \& Cos-Gayón, F. (2019). Analysis of Twitter messages using big data tools to evaluate and locate the activity in the city of Valencia (Spain). Cities, 86, 37-50. https://doi.org/10.1016/j.cities.2018.12.014

Martin, N., Rice, J., \& Arthur, D. (2019). Advancing social media derived information messaging and management: A multi-mode development perspective. International Journal of Information Management, 102021. https://doi.org/10.1016/j.ijinfomgt.2019.10.006

Martínez-Rojas, M., Pardo-Ferreira, M. del C., \& Rubio-Romero, J.C. (2018). Twitter as a tool for the management and analysis of emergency situations: A systematic literature review. International Journal of Information Management, 43, 196-208. https://doi.org/10.1016/j.ijinfomgt.2018.07.008

Molinillo, S., Anaya-Sánchez, R., \& Liébana-Cabanillas, F. (2019). Analyzing the effect of social support and community factors on customer engagement and its impact on loyalty behaviors 
toward social commerce websites. Computers in Human Behavior, 108, 105980. https://doi.org/10.1016/j.chb.2019.04.004

Molinillo, S., Anaya-Sánchez, R., Morrison, A.M., \& Coca-Stefaniak, J.A. (2019). Smart city communication via social media: Analysing residents' and visitors' engagement. Cities, 94, 247-255. https://doi.org/10.1016/j.cities.2019.06.003

Neuendorf, K.A. (2017). The Content Analysis Guidebook. In SAGE Publication.

Ngamassi, L., Ramakrishnan, T., \& Rahman, S. (2016). Use of social media for disaster management: A prescriptive framework. Journal of Organizational and End User Computing, 28(3), 122-140. https://doi.org/10.4018/JOEUC.2016070108

Nicola, M., Alsafi, Z., Sohrabi, C., Kerwan, A., Al-Jabir, A., Iosifidis, C., \& Agha, R. (2020). The Socio-Economic Implications of the Coronavirus and COVID-19 Pandemic: A Review. In International Journal of Surgery, 78, 185-193. https://doi.org/10.1016/j.ijsu.2020.04.018

Panagiotopoulos, P., Barnett, J., Bigdeli, A.Z., \& Sams, S. (2016). Social media in emergency management: Twitter as a tool for communicating risks to the public. Technological Forecasting and Social Change, 111, 86-96. https://doi.org/10.1016/j.techfore.2016.06.010

Park, H., Reber, B.H., \& Chon, M.G. (2016). Tweeting as health communication: Health organizations use of twitter for health promotion and public engagement. Journal of Health Communication, 21(2), 188-198. https://doi.org/10.1080/10810730.2015.1058435

Pezanowski, S., MacEachren, A.M., Savelyev, A., \& Robinson, A.C. (2018). SensePlace3: a geovisual framework to analyze place-time-attribute information in social media. Cartography and Geographic Information Science, 45(5), 437. https://doi.org/10.1080/15230406.2017.1370391

Qiu, W., Rutherford, S., Chu, C., Mao, A., \& Hou, X. (2011). Risk Communication and Public Health (2nd Edition). Australian and New Zealand Journal of Public Health, 35(4), 396-397. https://doi.org/10.1111/j.1753-6405.2011.00750.x

Roberts, H., Seymour, B., Fish, S.A., Robinson, E., \& Zuckerman, E. (2017). Digital Health Communication and Global Public Influence: A Study of the Ebola Epidemic. Journal of Health Communication, 22(0), 51-58. https://doi.org/10.1080/10810730.2016.1209598

Sabani, A., Deng, H., \& Thai, V.V. (2019). Evaluating the Performance of E-Government in Indonesia : A Thematic Analysis. ICEGOV, 435-440. https://doi.org/10.1145/3326365.3326422

Son, J., Lee, H.K., Jin, S., \& Lee, J. (2019). Content features of tweets for effective communication during disasters: A media synchronicity theory perspective. International Journal of Information Management, 45, 56-68. https://doi.org/10.1016/j.ijinfomgt.2018.10.012

UNDCO and WHO. (2020). Strategic Preparedness and Response Plan on COVID-19 by WHO. Printed in Geneva, Switzerland., (12 February), 20. https://www.who.int/publications-detail/strategicpreparedness-and-response-plan-for-the-new-coronavirus

Wang, T., Hussain, A., Bhutta, M.N.M., \& Cao, Y. (2019). Enabling bidirectional traffic mobility for ITS simulation in smart city environments. Future Generation Computer Systems, 92, 342-356. https://doi.org/10.1016/j.future.2018.10.015

Wang, Y., Wang, T., Ye, X., Zhu, J., \& Lee, J. (2016). Using social media for emergency response and urban sustainability: A case study of the 2012 Beijing rainstorm. Sustainability (Switzerland), 8(1), 1-17. https://doi.org/10.3390/su8010025

WHO. (2019). 2019 Novel Coronavirus (2019-nCoV) Strategic Preparedness and Response Plan for the South-east Asia Region 1. In World Health Organization South-East Asia.

WHO. (2020a). Covid-19 Strategic Praparedness and Response Plan Country Praparedness and Response Status for Covid-19 as pf 13 April 2020. In World Health Organization. 
WHO. (2020b). Getting your workplace ready for COVID-19. World Health Organization, 1-8. www.WHO.int.

WHO. (2020c). Risk communication and community engagement readiness and initial response for novel coronaviruses (nCoV). WHO, (January), 1-3.

Woolf, N.H., \& Silver, C. (2018). Qualitative Analysis Using Nvivo, The Five Level QDA Method. In Routledge, New Yorl and London: Routledge, 1-1235.

Xiao, Y., \& Torok, M.E. (2020). Taking the right measures to control COVID-19. The Lancet Infectious Diseases, 20(5), 253-524. https://doi.org/10.1016/S1473-3099(20)30152-3

Yoo, E., Rand, W., Eftekhar, M., \& Rabinovich, E. (2016). Evaluating information diffusion speed and its determinants in social media networks during humanitarian crises. Journal of Operations Management, 45, 123-133. https://doi.org/10.1016/j.jom.2016.05.007

Zhang, C.B., \& Lin, Y.H. (2015). Exploring interactive communication using social media. Service Industries Journal, 35(11-12), 670-693. https://doi.org/10.1080/02642069.2015.1064396

Zhang, C., Fan, C., Yao, W., Hu, X., \& Mostafavi, A. (2019). Social media for intelligent public information and warning in disasters: An interdisciplinary review. International Journal of Information Management, 49, 190-207. https://doi.org/10.1016/j.ijinfomgt.2019.04.004 